\title{
SEBUAH DILEMA PERTANIAN ORGANIK TERKAIT EMISI METAN (A Dilemma on Organic Farming in Relation to Methane Emission)
}

\author{
Ernitha Panjaitan $^{1,2, *}$, Didik Indradewa ${ }^{3}$, Edhi Martono ${ }^{4}$ dan Junun Sartohadi ${ }^{5}$ \\ ${ }^{1}$ Fakultas Pertanian, Universitas Methodist Indonesia, \\ Jl. Harmonika Baru Psr.II, Tanjung Sari, Medan 20131. \\ ${ }^{2}$ Program Doktor pada Program Studi Ilmu Lingkungan, Sekolah Pasca Sarjana, \\ Universitas Gadjah Mada, Sekip Utara, Yogyakarta 55281. \\ ${ }^{3}$ Bagian Agronomi Fakultas Pertanian, Universitas Gadjah Mada, Bulaksumur, Yogyakarta 55281 \\ ${ }^{4}$ Bagian Perlindungan Tanaman Fakultas, Pertanian Universitas Gadjah Mada, \\ Bulaksumur, Yogyakarta 55281. \\ ${ }^{5}$ Fakultas Geografi, Universitas Gadjah Mada, Sekip Utara, Yogyakarta 55281. \\ *Penulis korespondensi. Tel: (061) 8212162. Fax,: (061) 8212162. \\ Email : ernitha2005@yahoo.co.id.
}

Diterima: 9 September 2014

Disetujui: 5 Desember 2014

\begin{abstract}
Abstrak
Gas metana $\left(\mathrm{CH}_{4}\right)$ adalah salah satu gas rumah kaca yang cukup berperan setelah $\mathrm{CO}_{2}$. Peningkatan metana di atmosfer belakangan ini perlu diantisipasi mengingat daya pemanasan global yang ditimbulkannya per satu molekul gas metana di troposfer 21 kali lebih tinggi daripada daya pemanasan satu molekul $\mathrm{CO}_{2}$. Tanah sawah adalah salah satu kontributor gas metana sekitar 10-15\%. Metana diproduksi sebagai hasil akhir dari proses dekomposisi mikrobial bahan organik secara anaerobik oleh bakteri metanogen. Emisi gas metana ditentukan oleh pengelolaan air, pengolahan tanah, varietas, dan iklim. Seiring dengan kesadaran masyarakat terhadap produk pangan yang sehat, serta ramah lingkungan, maka permintaan akan beras organik meningkat. Namun, budidaya padi organik menghadapi dilema yaitu peningkatan produksi gas metana lebih tinggi daripada budidaya padi konvensional.
\end{abstract}

Kata kunci: bahan organik, emisi metana, padi, pemanasan global, pertanian konvensional, pertanian organik.

\begin{abstract}
Methane $\left(\mathrm{CH}_{4}\right)$ is the second main type of gas after $\mathrm{CO}_{2}$ in contributing global warning. The increasing of methane in our atmosphere should be anticipated because its effect of single molecule of methane to the warning up our trophosphere is 21 times higher than single molecule of $\mathrm{CO}_{2}$. Paddy field soils as one of contributors produce 10-15\% of methane in our atmosphere. The methane is produced as results of microbial processes on aerobic organic matters decomposition by metanogene bacteria. The amount of methane production is determined by soil water management, crop species, and climate. In line with the community awarness in healthy and environmental friendly product of food, the demand of organic rice has increased. However, the organic farming has trade off situation due to its methane production higher than the conventional farming.
\end{abstract}

Keywords: organic matters, methane, paddy, global warning, conventional farming, organic farming.

\section{PENDAHULUAN}

Salah satu tantangan pembangunan pada sektor pertanian khususnya tanaman pangan adalah kemampuan sektor pertanian menyediakan pangan yang cukup, baik kuantitas maupun kualitasnya bagi penduduk yang jumlahnya terus bertambah dan mampu meningkatkan kesejahteraan petani, serta tetap menjaga kelestarian sumber daya alam. Beras merupakan makanan pokok sekitar 2,7 milyar orang atau hampir separuh penduduk dunia, khususnya di negara-negara Asia. Pada tahun 2015, konsumen beras dunia bahkan diperkirakan akan meningkat hingga mencapai 4 milyar orang. Untuk memenuhi kebutuhan yang terus meningkat tersebut, produksi beras dunia diproyeksikan harus ditingkatkan sebesar 68\% dari produksi tahun 1989 sebesar 473 juta ton menjadi 781 juta ton pada tahun 2020 (Anonim, 1994).

Produksi padi nasional negara Indonesia tahun 2013 mencapai 71,28 juta ton gabah kering giling (GKG) atau naik 3,22\% (3,22 juta ton) dibanding produksi tahun 2012 (Anonim, 2014). Kenaikan produksi padi yang telah dicapai pada kenyataannya masih belum dapat memenuhi kebutuhan pangan masyarakat Indonesia. Menurut Sintani (2006), tuntutan peningkatan produksi beras nasional adalah 0,8-1 \% setiap tahun sebagai antisipasi dalam mengimbangi laju pertambahan jumlah penduduk 1,5\% setiap tahunnya. 
Upaya intensifikasi pertanian dengan masukan bahan agrokimia yaitu pupuk dan pestisida dengan tujuan meningkatkan produktivitas lahan, dilakukan dengan gencar. Upaya ekstensifikasi terkendala lahan marginal serta semakin banyak alih fungsi lahan pertanian. Penggunaan bahan-bahan agrokimia ini secara terus menerus dan dalam dosis yang berlebihan, pada kenyataannya menyebabkan kerusakan sifat fisik, kimia dan biologi tanah, pencemaran terhadap tanah, air dan udara, serta menurunkan kualitas produk pangan (Mangkoedihardja, 1999; Adiningsih, 2005).

Sistem pertanian organik adalah sistem pertanian dengan masukan eksternal rendah (low external input), yaitu mengurangi penggunaan input eksternal seperti pupuk kimia dan pestisida kimia tetapi menggantikannya dengan input internal tanpa bahan kimia tetapi mengandalkan prinsip daur ulang hara secara hayati. Seiring dengan kesadaran masyarakat yang semakin tinggi akan produk pangan yang sehat dan tidak mencemari lingkungan, maka pada dasawarsa ini permintaan akan produk pangan organik semakin meningkat. Proyeksi produksi pasar padi organik tahun 2009 sebesar 577.080 kuintal, sedangkan kebutuhan pasar sebesar 1.141.102 kuintal.

Salah satu isu lingkungan berkaitan dengan produksi pertanian khususnya beras adalah anggapan bahwa kegiatan budidaya padi sawah penyebab utama peningkatan pemanasan global. Hal ini didasarkan pada hasil penelitian yang menunjukkan emisi metana $\left(\mathrm{CH}_{4}\right)$ yang tinggi dari tanah sawah beririgasi. Metana $\left(\mathrm{CH}_{4}\right)$ merupakan salah satu gas rumah kaca utama yang dapat menyerap radiasi infra merah sehingga berkontribusi terhadap pemanasan global (Neue dan Sass, 1994, Hossain dkk., 2007). Menurut Zeigler (2005) dalam Wihardjaka (2011), setiap peningkatan suhu $1{ }^{\circ} \mathrm{C}$ akan menurunkan hasil padi 0,5 ton per hektar, karena peningkatan suhu akan menghambat fase pengisian bulir padi dan menyebabkan penurunan hasil gabah.

Tanah sawah diperkirakan menyumbangkan 20-120 juta ton $\mathrm{CH}_{4}$ ke atmosfer, atau sekitar $12,5 \%$ dari sumber total tahunan yaitu sekitar 470650 juta ton $\mathrm{CH}_{4}$. Emisi total tersebut berasal dari total luasan lahan dunia yang digunakan untuk budidaya padi sawah yang mencapai $1,45 \times 10^{6} \mathrm{~km}^{2}$ atau sekitar $10 \%$ dari total lahan pertanian dunia (Yagi dan Minami, 1990; Lelieveld dan Crutzen, 1993).

Kepedulian terhadap perubahan iklim global pada masa ini yang salah satu penyebabnya bersumber dari kegiatan budidaya padi pada tanah sawah, mengarahkan perhatian dunia untuk mengupayakan mitigasi gas metana tersebut, khususnya bagi negara-negara penghasil dan pengkonsumsi beras. Menghadapi permasalahan tentang upaya peningkatan produksi padi pada satu sisi, serta upaya menanggulangi kerusakan lingkungan akibat pencemaran dari sektor pertanian pada sisi lainnya, adalah sebuah dilema, sehingga perlu pemikiran yang serius untuk mengatasi persoalan tersebut. Diperlukan suatu sistem pertanian yang mampu memperbaiki produktivitas lahan dengan tidak merusak lingkungan serta secara ekonomi menguntungkan dan secara sosial dapat diterima masyarakat. Tujuan penelitian ini adalah untuk mengkaji budidaya padi organik di lahan sawah terhadap pencemaran lingkungan dibanding dengan konvensional.

\section{METODE PENELITIAN}

Metode penelitian ini terkait dengan objek kajian menggunakan metode survey, sifat uraian yang digunakan adalah deskriptif. Kaitannya dengan populasi penelitian menggunakan sampel, pengambilan sampel secara Quota Sampling. Hal ini berdasarkan jumlah sampel fisik dari lahan milik petani dapat mewakili luas lahan budidaya padi organik di wilayah penelitian. Tingkat pencemaran lingkungan merupakan unit analisis dalam penelitian ini.

Penelitian dilaksanakan pada sistem pertanian organik dan pertanian konvensional tanaman padi sawah, di dua kecamatan dan lima desa, Kabupaten Deli Serdang Propinsi Sumatera Utara. Pertimbangan dalam memilih lokasi adalah bahwa Kabupaten Deli Serdang merupakan salah satu sentra pertanaman padi sawah organik di Propinsi Sumatera Utara. Petani di lokasi penelitian telah menerapkan sistem budidaya padi sawah secara organik selama lebih kurang sepuluh tahun. Penelitian ini dilakukan pada musim tanam kemarau dan musim tanam penghujan 2009/2010.

Sumber data adalah data primer dan data sekunder. Data primer bersumber dari pengambilan data pencemaran udara dari lahan petani yang melakukan budidaya padi organik dan konvensional di lokasi penelitian. Data sekunder, yaitu data telah disusun dalam bentuk dokumen-dokumen, bersumber dari beberapa instansi yang memiliki kebijakan terhadap pengelolaan lingkungan terkait.

Jenis data yang dikumpulkan adalah data kuantitatif, yaitu emisi metana dari udara. Data kuantitatif diperoleh dari data primer dan data sekunder atau gabungan data primer dan data sekunder. Analisis fluk metana menggunakan metoda chamber. Data yang terkumpul dianalisis secara statistik untuk menjawab permasalahan tentang pengaruh pertanian organik pada tanaman padi sawah terhadap pencemaran udara, menggunakan uji ANOVA. 
Fluks gas metana diukur pada akhir fase vegetatif tanaman menggunakan sungkup tertutup. Sungkup tertutup (closed chamber) yang digunakan untuk mengambil sampel gas metana berukuran 20 $\mathrm{cm} \times 20 \mathrm{~cm} \times 100 \mathrm{~cm}$. Sungkup terbuat dari pleksiglas dilengkapi dengan termometer yang terpasang pada bagian atas sungkup. Sungkup setiap petakan diletakkan secara acak sebelum pengambilan sampel gas yang pertama, dan pada posisi yang sama untuk pengambilan sampel gas berikutnya.

Pengambilan sampel udara dalam sungkup dilakukan pada pukul 06.00 sampai pukul 09.00 pagi, diambil empat kali dengan interval waktu pengambilan $5,10,15$, dan 20 setelah peletakan sungkup, menggunakan injeksi propilen ukuran 10 $\mathrm{mL}$ berkatup. Setiap pengambilan sampel gas, perubahan suhu dalam sungkup diukur. Sampel gas dianalisis menggunakan alat gas kromatografi gas (GC) yang dilengkapi dengan FID (Flame Ionization Detector) untuk menetapkan fluk metana dengan metode yang digunakan International Rice Research Institute (Cortons dkk., 2000; Jain dkk., 2000; Ko dan Kang, 2000). Kadar gas dari sampel pengambilan di lapangan dihitung menggunakan persamaan (1) berikut (Khalil dkk.,1991).

$\mathrm{E}=\frac{d c}{d t} \frac{V c h}{A c h} \frac{m W}{m V} \frac{273,2}{(273,2+T)}$
E : Emisi gas $\mathrm{CH}_{4}\left(\mathrm{mg} / \mathrm{m}^{2} /\right.$ hari $)$

dc/dt : Perbedaan konsentrasi $\mathrm{CH}_{4}$ per waktu

(ppm/menit)

Vch : Volume boks $\left(\mathrm{m}^{3}\right)$

Ach : Luas boks $\left(\mathrm{m}^{2}\right)$

$\mathrm{mW}$ : Berat molekul $\mathrm{CH}_{4}(\mathrm{~g})$

$\mathrm{mV}$ : Volume molekul $\mathrm{CH}_{4}(22,41 \mathrm{~L})$

$\mathrm{T}$ : Temperatur rata-rata selama pengambilan sampel $\left({ }^{\circ} \mathrm{C}\right)$.

\section{HASIL DAN PEMBAHASAN}

\section{Emisi Metana dari Tanah Sawah}

Emisi metana dari areal persawahan adalah hasil dari produksi dan oksidasi metana dalam tanah dan pengangkutan metana dari tanah ke atmosfer melalui rongga vaskular tanaman padi $(\mathrm{Lu}$ dkk., 2000). Produki metana bersumber dari dekomposisi anaerobik bahan organik (Setyanto, dkk., 2004). Hasil analisis keragaman menunjukkan interaksi antara sistem pertanian dan musim tanam tidak berpengaruh nyata terhadap fluk metana. Musim tanam dan cara budidaya berpengaruh secara nyata terhadap besar fluk metana pada lahan sawah. Kisaran rata-rata fluk metana pada cara budidaya organik dan konvensional untuk musin tanam kemarau dan musim penghujan disajikan dalam Tabel 1.

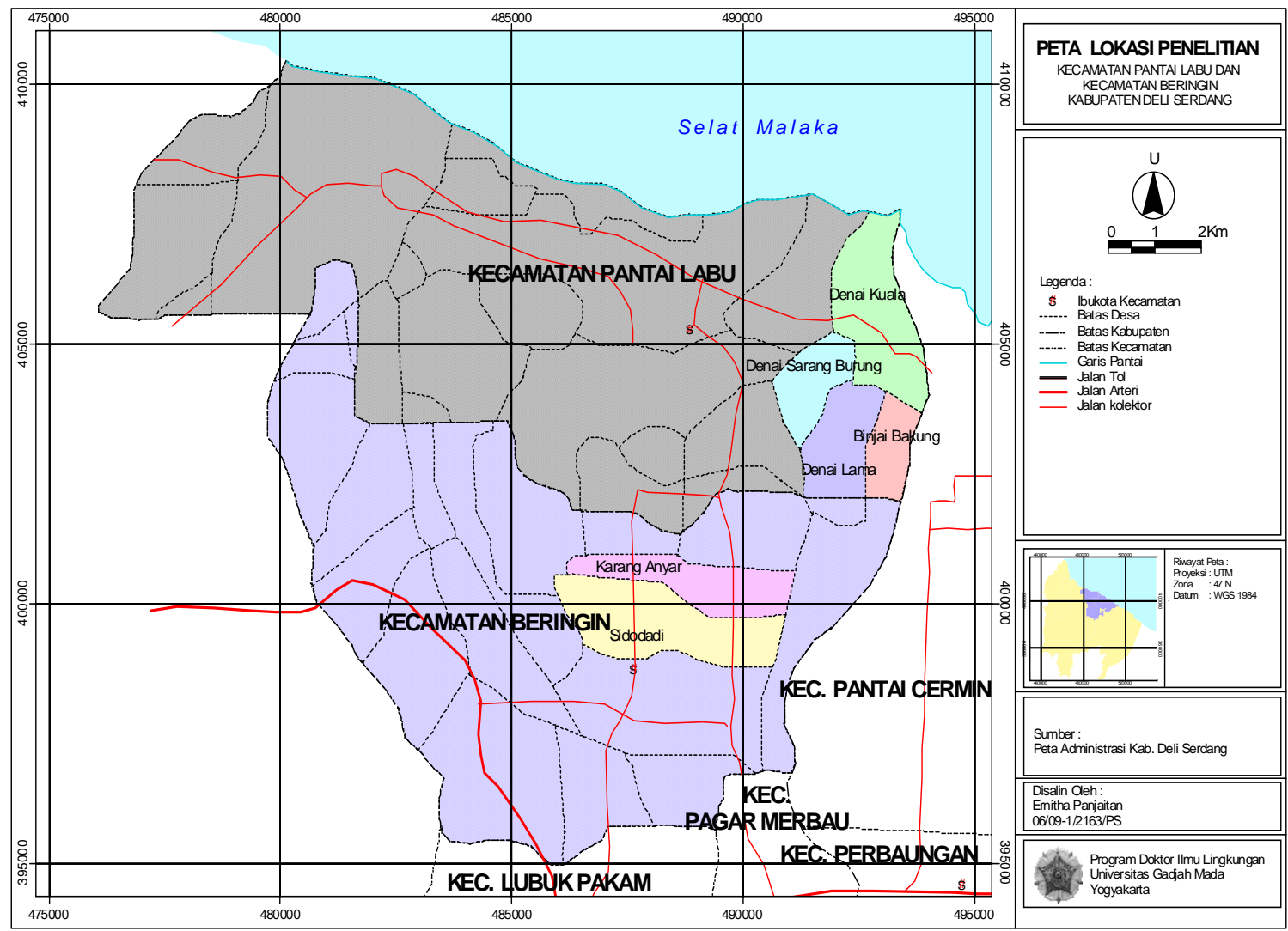

Gambar 1. Denah lokasi penelitian Kecamatan Beringin dan Pantai Labu Kabupaten Deli Serdang. 
Tabel 1. Pengaruh musim tanam kemarau dan hujan terhadap fluk metana (mg/( $\left.\left.\mathrm{m}^{2} . m e n i t\right)\right)$ pada pertanaman padi sawah.

\begin{tabular}{lccc}
\hline Lokasi & Sistem pertanian & \multicolumn{2}{c}{ Fluk metana $\left(\mathrm{mg} /\left(\mathrm{m}^{2}\right.\right.$. menit $)$} \\
\cline { 3 - 4 } Denai Lama & & Musim kemarau & Musim hujan \\
\cline { 3 - 4 } Denai Kuala & Organik & 0,586 & 0,875 \\
& Konvensional & 0,516 & 0,643 \\
Binjai Bakung & Organik & 0,551 & 0,713 \\
& Konvensional & 0,454 & 0,659 \\
Sidodadi & Organik & 0,616 & 0,778 \\
& Konvensional & 0,466 & 0,663 \\
Karanganyer & Organik & 0,632 & 0,894 \\
& Konvensional & 0,456 & 0,709 \\
& Organik & 0,582 & 0,674 \\
\hline
\end{tabular}

Pada musim hujan pelepasan metana dari lahan sawah lebih besar dibandingkan dengan musim kemarau. Curah hujan atau distribusi curah hujan bulanan pada periode musim kemarau (Juni September 2009), berada pada kisaran 49-546 mm, sedangkan pada periode musim hujan (Oktober 2009 - Februari 2010), curah hujan bulanan berkisar 65-272 mm. Curah hujan menyebar tidak merata, dimana curah hujan selama tahun 2009 sebesar $2.384 \mathrm{~mm} / \mathrm{tahun}$, dan curah hujan selama tahun 2010 sebesar 1.605 mm/tahun. Curah hujan tertinggi terjadi pada bulan September sebesar 546 $\mathrm{mm} /$ bulan dan terendah terjadi pada bulan Februari 2009 sebesar $10 \mathrm{~mm} /$ bulan.

Kelembaban rata-rata bulanan adalah berkisar $84 \%$, tertinggi adalah pada bulan Oktober yaitu 86 $\%$, dan terendah pada bulan Juni $81 \%$. Temperatur rata-rata bulanan adalah berkisar $27,1{ }^{\circ} \mathrm{C}$, dengan temperatur tertinggi pada bulan Juni sebesar 28,1 ${ }^{\circ} \mathrm{C}$, dan terendah pada bulan Januari 2009 sebesar 26,0 ${ }^{\circ} \mathrm{C}$. Lama penyinaran matahari rata-rata tahunan adalah $49,1 \%$.

Emisi metana pada musim penghujan adalah lebih tinggi dibanding pada musim kemarau (Tabel 2). Curah hujan yang intensif selama musim tanam penghujan mengakibatkan kondisi lingkungan yang menguntungkan karena ketersediaan air hujan mencukupi bagi pertumbuhan tanaman yang lebih baik. Salah satu indikator pertumbuhan tanaman yang baik adalah produksi eksudat akar tanaman padi yang lebih aktif. Eksudat akar menyediakan substrat untuk bakteri metanogen ataupun bakteri metanotrof yang terdiri atas karbohidrat, asamasam organik, asam-asam amino, dan senyawa fenolik sehingga eksudat akar tersebut dapat mempertinggi emisi metana (Das dan Baruah, 2008).

Di samping itu kemasaman tanah mempengaruhi pembentukan metana dalam tanah. Peningkatan kemasaman tanah akan menurunkan fluk gas metana. Hasil pengukuran $\mathrm{pH}$ tanah menunjukkan rerata $\mathrm{pH}$ tanah padi sawah yang ditanam pada musim kemarau adalah 5,95 lebih
Tabel 2. Rerata fluk metana sistem pertanian organik dan konvensional pada musim tanam kemarau dan penghujan.

\begin{tabular}{lc}
\hline Perlakuan & Fluk metana $\left(\mathrm{mg} /\left(\mathrm{m}^{2}\right.\right.$. menit $\left.)\right)$ \\
\hline Kemarau (Mt1) & $0,53 \mathrm{a}$ \\
Penghujan (Mt2) & $0,74 \mathrm{~b}$ \\
Organik (S1) & $0,69 \mathrm{~b}$ \\
Konvensional (S2) $_{\mathrm{BNJ}_{0,05}}$ & $0,58 \mathrm{a}$ \\
\hline $\mathrm{K}^{2}$ & 0,04 \\
\hline
\end{tabular}

Keterangan :Angka yang diikuti oleh huruf yang sama dalam kolom yang sama berarti berbeda tidak nyata pada taraf uji $5 \%$

rendah dibanding rerata $\mathrm{pH}$ tanah padi sawah yang ditanam pada musim penghujan yaitu 6,21. Bakteri metanogen pada umumnya tumbuh pada kisaran $\mathrm{pH}$ mendekati 6-8, dan $\mathrm{pH}$ optimum untuk pembentukan gas metana adalah 7. Pada tanah dengan kemasaman tinggi, aktivitas bakteri metanogen berkurang yang berpengaruh terhadap penurunan produksi metana dalam tanah (Neue dkk., 1990).

Pada Tabel 2, hasil analisis menunjukkan terjadi peningkatan emisi metana pada sistem pertanian organik dibandingkan sistem pertanian konvensional. Menurut Lu dkk., (2000) dan Mitra dkk., (2013), bahwa emisi metana dari areal persawahan adalah hasil dari produksi dan oksidasi metana dalam tanah dan pengangkutan $\mathrm{CH}_{4}$ dari tanah ke atmosfer melalui rongga vaskular tanaman padi. Produksi metana umumnya diperikan sebagai fungsi ketersediaan substrat organik dan oksidanoksidan, dan beberapa sifat fisikokimia tanah seperti kemasaman tanah, potensial redoks, tekstur tanah, suhu, pertumbuhan tanaman, dan varietas tanaman. Peran tanaman padi dalam dinamika metana yaitu sumber substrat untuk metanogen dalam bentuk eksudat tanaman, akar, sisa tanaman periode sebelumnya, transpor metana melalui rongga udara jaringan aerenkhima, dan tekanan $\mathrm{O}_{2}$ pada daerah perakaran (rhizosfer). Faktor ini merupakan salah satu faktor penting dalam mengurangi fluk $\mathrm{CH}_{4}$ melalui tanaman dengan 
mengoksidasi $\mathrm{CH}_{4}$ di daerah perakaran dan menghambat aktivitas bakteri metanogen (Wihardjaka, 2011).

Tanaman padi melepaskan gas $\mathrm{CH}_{4}$ melalui dekomposisi bahan organik, yang berlangsung secara anaerobik akibat adanya penggenangan air. Petani padi sawah organik pada daerah penelitian menggunakan pupuk kompos yang dibuat sendiri berasal dari bahan baku jerami dan kotoran ternak. Selama musim tanam, pupuk kompos diberikan dengan takaran 2 - 2,5 ton/ha ditambah dengan dolomit sebanyak 0,075 ton/ha. Sistem pertanian padi sawah secara organik dengan mengaplikasikan bahan organik yang belum terdekomposisi sempurna sebagai pupuk, adalah kemungkinan penyebab tingkat pelepasan gas metana yang lebih tinggi dibanding lahan sawah konvensional. Schutz dkk., (1990) menemukan bahwa penambahan jerami kering 3 ton/ha menghasilkan emisi metana 0,5 kali lebih tinggi dibanding tanpa pemberian jerami, dua kali lebih tinggi pada penambahan 5 ton/ha dan 2,4 kali lebih tinggi pada penambahan 12 ton/ha. Selanjutnya, Yagi dan Minami (1990) menemukan bahwa penambahan jerami 6 ton/ha dapat meningkatkan emisi metana 1,8-3,3 kali lebih besar dibanding hanya pemberian pupuk anorganik. Pada penambahan 9 ton/ha emisi metana yang dihasilkan 3,5 kali lebih besar. Penambahan jerami yang sudah dikomposkan (terhumifikasi), dilaporkan tidak memberi emisi yang tinggi (Setyanto dan Hidayat, 2001).

Faktor penyebab lain adalah padi yang dibudidayakan secara konvensional membutuhkan pupuk $\mathrm{N}$ yang cukup tinggi selama masa hidupnya. Pemupukan N sebagai salah satu aspek penting dalam peningkatan produksi padi diduga berpengaruh terhadap pembentukan gas metana. Petani konvensional pada daerah penelitian menggunakan pupuk urea sebesar $300 \mathrm{~kg} / \mathrm{ha}$, TSP 75-175 kg/ha dan KCl $50 \mathrm{~kg} / \mathrm{ha}$. Pupuk urea diberikan dua kali, yaitu pada 3-4 minggu, 6-8 minggu setelah tanam. Urea disebarkan dan diinjak agar terbenam. Pupuk TSP diberikan satu hari sebelum tanam dengan cara disebarkan dan dibenamkan. Pupuk KCl diberikan dua kali yaitu pada saat tanam dan saat menjelang keluar malai. Hasil penelitian Suharsih dkk., (2002) yang menunjukkan bahwa penggunaan urea pril dapat menekan emisi gas metana sebesar 3,8\% dibandingkan dengan tanpa pupuk N.

Dengan demikian besarnya emisi gas metana dari lahan sawah pada daerah penelitian dipengaruhi oleh beberapa faktor, antara lain pengelolaan air irigasi, suhu tanah, bahan organik yang digunakan, jenis dan frekuensi pemberian pupuk N, dan musim tanam (Kimura dkk, 1991;
Makarim dkk., 1996; Neue dan Roger, 1993; Wihardjaka dkk., 1999; Yagi dan Minami, 1990; Lu dkk., 2000; Setyanto dkk., 2004).

Hasil pengukuran langsung emisi metana ratarata di tanah sawah padi irigasi yang dibudidayakan secara organik adalah sebesar $36,3 \times 10^{-7} \mathrm{Tg}$ $\mathrm{CH}_{4} /$ (ha.tahun) dan dari lahan sawah konvensional $30,5 \times 10^{-7} \mathrm{Tg} \mathrm{CH}_{4} /$ (ha.tahun). Emisi gas metana dari tanah sawah pada musim hujan sebesar 37,3 x 10-7 $\mathrm{Tg} \mathrm{CH}_{4} /$ (ha.tahun), pada musim kemarau sebesar 26,7 $\times 10^{-7} \mathrm{Tg} \mathrm{CH}_{4} /$ (ha.tahun). Secara kuantitatif besar dan pola source-sink emisi gas metana pada tanah sawah dalam musim tanam belum banyak diketahui, maka kontribusinya dikonversikan dengan $\mathrm{CO}_{2}$. Potensi penyerapan dan pemanasan lingkungan di tanah sawah padi irigasi yang dibudidayakan secara organik, konvensional, pada musim hujan dan musim kemarau berturut-turut adalah sebesar $762,3 \times 10^{-7}, 640,5 \times 10^{-7}, 783,3 \times 10^{-7}$ dan $560,7 \times 10^{-7} \mathrm{Tg} \mathrm{CH}_{4} /$ (ha.tahun). Secara umum ambang batas global konsentrasi $\mathrm{CO}_{2}$ adalah 350 ppm, maka dipandang perlu mengupayakan mitigasi metana dari lahan sawah pada lokasi penelitian. Luas lahan padi sawah di Kabupaten Deli Serdang adalah sebesar 90.601 ha pada tahun 2012, bilamana diasumsikan emisi gas metana ratarata adalah sebesar $35 \times 10^{-7} \mathrm{Tg} \mathrm{CH}_{4} /$ (ha.tahun), maka kontribusi gas metana dari tanah sawah di Kabupaten Deli Serdang adalah berkisar 0,32 Tg $\mathrm{CH}_{4}$ /tahun, dan untuk luasan lahan sawah di Indonesia sebesar 4.417.581,92 ha diperoleh besar emisi metana $15 \mathrm{Tg} \mathrm{CH}_{4} /$ tahun. Emisi gas metana dari tanah sawah di China dan India berkisar 26-37 $\mathrm{Tg} \mathrm{CH}_{4} /$ tahun (Neue dkk., 1994).

Indonesia berkomitmen menurunkan gas rumah kaca $26 \%$ dengan kemampuan sendiri dan menjadi $41 \%$ dengan bantuan luar negeri sampai tahun 2020. Komitmen ini tertuang dalam Rencana Aksi Nasional (RAN) GRK yang diprakarsai oleh Bappenas dan disahkan melalui Perpres 61 tahun 2011. Ada lima sektor yang terlibat secara langsung, yaitu kehutanan dan lahan gambut, limbah, pertanian, industri dan energi. Berdasarkan komitmen ini maka negara Indonesia berkewajiban menurunkan emisinya sampai tahun 2020, oleh karena itu upaya mitigasi perlu dilaksanakan.

\section{KESIMPULAN}

Hasil penelitian menunjukkan bahwa terdapat perbedaan emisi gas metana antara sistem pertanian organik dan sistem pertanian konvensional. Rerata emisi gas metana dari budidaya padi sawah secara

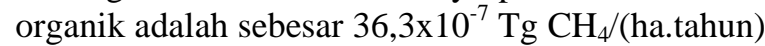
dan dari padi konvensional $30,5 \times 10^{-7} \mathrm{Tg}$ $\mathrm{CH}_{4} /$ (ha.tahun). Perbedaan emisi gas metana ini 
juga terjadi untuk budidaya padi pada musim hujan dan pada musim kemarau. Rerata emisi gas metana dari tanah sawah pada musim hujan sebesar $37,3 \times 10^{-7} \mathrm{Tg} \mathrm{CH}_{4} /$ (ha.tahun), pada musim kemarau sebesar $26,7 \times 10^{-7} \mathrm{Tg} \mathrm{CH}_{4} /$ (ha.tahun).

\section{DAFTAR PUSTAKA}

Adiningsih, 2005. Peranan Bahan Organik Tanah Dalam Meningkatkan Kualitas dan Produktivitas Lahan Pertanian. Materi Workshop dan Kongres Nasional II Masyarakat Pertanian Organik Indonesia. Jakarta, 21-22 Desember 2005.

Anonim, 1994. Soil and Plant Sampling and Measurements, Part 1 - Soil Sampling and Measurements. International Rice Research Institute. Los Banos.

Anonim, 2014. Statistik Indonesia 2014. Badan Pusat Statistik. Jakarta.

Cortons, T.M., Bajita, J.B., Grospe, F.S., Pamplona, R.R., Aziz C.A. Jr., Wassmann, R., Lantin, R. S., dan Buendia, L.V., 2000. Methane Emission from Irrigated and intensively Managed Rice Fields in Central Luzon, Philippines. Nutr. Cycl.Agroecosyst. 58:37-53.

Das, K., dan Baruah, K.K., 2008, a Comparison of Growth and Photosynthetic Characteristics of Two Improved Rice Cultivars on Methane Emission from Rainfed Agroecosystem of Northeast India. Agric. Ecosyst. Environ. 124:105-113.

Hossain, T.S., Hideki S., Hideto, U., dan Sheikh M.R., 2007. Adoption of Organic Rice For Sustainable Development In Bangladesh. Journal of Organic Systems, 2(2):1-11.

Jain, M.C., Kumar, S., Wassmann, R., Mitra, S., Singh, S.D., Singh, J.P., Singh, R., Yadav, A.K., dan Gupta, S., 2000. Methane Emissions from Irrigated Rice Fields in Northen India, New Delhi. Nutr. Cycl. Agroecosyst. 58:75-83.

Kimura, M., Miura, Y., Watanabe, A., Katoh, T., dan Haraguchi, H., 1991. Methane Emission from Paddy Field (Part 1). Effect of Fertilization, Growth Stageand Midsummer Drainage: Pot Experiment. Environ. Sci. 4:265-271.

Khalil, M.A.K., Rasmussen,. R.A., Wang, M.X., dan Ren, L., 1991. Methane Emissions from Rice Fields in China. Environ. Sci. Technol., 25:979-981.

Ko, J.Y., dan Kang, H.W., 2000. The Effect of Cultural Practices on Methane Emission from Rice Fields. Nutr. Cycl. Agroecosyst. 58:311314.
Lelieveld, J., dan Crutzen, P.J., 1993. Methane Emission into The Atmosphere, An Overview. p. 17-25 in van Amstel, A.R. (Ed.).Methane and Nitrous Oxide,Methods in National Emission Inventories and Option for Control. Proc.Intern. IPCC Workshop. Amsterdam. 3-5 February 1993.

Lu, Y., Arah, J.R.M., Wassmann, R., dan Neue, H.U., 2000. Simulation of Methane production in Anaerobic Rice Soils by A Simple TwoPool Model. Nutr. Cycl.Agroecosyst., 58:277283.

Makarim, A.K., Setyanto, P., dan Fagi, A.M., 1996. Suppressing Methane Emission from Rainfed Lowland Rice Field in Jakenan, Central Java. Paper presented at the International Symposium on Maximizing Sustainable Rice Yield through Improved Soil and Environmental Management. Khon Kaen.

Mangkoediharja, S., 1999. Ekotoksikologi Keteknikan. Jurusan Teknik LingkunganFTSP, ITS. Surabaya.

Mitra, S., Majumdar, D., dan Wassmann, R., 2012. Methane Production and Emission in Surface and Subsurface Rice Soils and Their Blends. Journal of Agriculture, Ecosystem and Environment, 158:94-102.

Neue, H.U., Becker-Heidmann, P. dan Scharpenseel, H.W., 1990. Organic Matter Dynamics, Soil Properties, and Cultural Practices in Ricelands and Their Relationship to Methane Production. p. 457 - 466 in Bouwman, A.F. (Ed.). Soil and The Greenhouse Effect. Wiley. Chichester, U.K.

Neue, H.U., dan Roger, P.A., 1993. Rice Agriculture : Factors Controlling Emmision. In : Khalil, M.A.K., and Shearer M. (Eds). Global Atmospheric Methane. NATO ASI/ARW Series.

Neue, H.U., dan Sass, R.L., 1994. Trace Gas Emission from Rice Fields. Environ. Sci. Research, 48:119-147.

Schutz, H., Seiler, W., dan Rennenberg, W., 1990. Soil and Land Use Related Sources and Sinks of Methane $\left(\mathrm{CH}_{4}\right)$ in The Context of The Global Methane Budget. In Bouwman, AF (Ed.), Soils and the Greenhouse Effects. John Wiley \& Sons, Chichester. pp. 269-285.

Setyanto, P., dan Hidayat, A., 2001. Identification of Less Greenhouse Gases Emissions Technologies in Agricultural Sector (Rice Cultivation). p. 6.1-6.14 in Identification of Less Greenhouse Gases Emission Technologies in Indonesia. Ministry of Environment, Republic of Indonesia, Jakarta. 
Setyanto, P., Rosenani, A.B., Boer, R., Fauziah, C.I. dan Khanif, M.J., 2004. The Effect of Rice Cultivars on Methane Emission from Irrigated Rice Field. Indonesian Journal of Agricultural Science, 5(1):20-31.

Sintani, 2006. Stop Konversi Lahan untuk Cegah Kerawanan Pangan. Sinar Tani 36:10.

Suharsih, S.T., dan Makarim, A.K., 2002. Pengaruh Cara Pengolahan Tanah dan Pengaturan Air terhadap Emisi Gas Metan pada Lahan Sawah Irigasi. p.59-64 dalam Prosiding Seminar Nasional Sistem Produksi Tanaman Pangan Berwawasan Lingkungan. Puslitbangtan. Bogor.

Wihardjaka, A., Setyanto, P., dan Makarim, A.K., 1999. Pengaruh Beberapa Varietas Padi terhadap Emisi Gas Metan pada Lahan Sawah. p. 62-71 dalam Risalah Seminar Hasil Penelitian Emisi Gas Rumah Kaca dan
Peningkatan Produktivitas Padi di Lahan Sawah. Puslitbangtan. Bogor.

Wihardjaka, A., 2011. Pengaruh Jerami Padi dan Bahan Penghambat Nitrifikasi Terhadap Emisi Gas Rumah Kaca (Metana dan Dinitrogen Oksida) Pada Ekosistem Sawah Tadah Hujan di Kabupaten Pati, Jawa Tengah. Disertasi. Program Pascasarjana Universitas Gadjah Mada, Yogyakarta. p. 265.

Yagi, K., dan Minami, K., 1990. Effect of Organic Matter Application of Methane Emission from Some Japanese Paddy Fields. Soil Sci. Plant Nutr. 36:599-610.

Zeigler, R.S., 2005. Rice Research and Development : Supply, Demand, Water, Climate, and Research Capacity. p. xiii - xxii in Sumarno, Suparyono, A. M. Fagi, dan. Adnyana, M.O. (Eds.). Rice Industry, Culture, and Environment. Book 1. Indonesian Center for Rice Research.. 